\title{
Atelectasis: An Uncommon Sign of Achalasia in Childhood
}

Olgu Sunumu

Case Report
Received/Geliș: 21.11.2019

Accepted/Kabul: 09.01.2020

Published Online: 29.04.2021

Aykut Eşki

Ege Üniversitesi Tıp Fakültesi, Çocuk Göğüs Hastalıkları Bilim

Dalı, İzmir, İzmir - Türkiye

aykuteski1984@gmail.com ORCID: 0000-0001-5378-5663

G. Kartal Öztürk 0000-0002-0793-9710

E. Demir 0000-0003-2736-8924

F. Gülen 0000-0002-5431-3913

Ege Üniversitesi Tıp Fakültesi, Çocuk Gögüs Hastalıkları

Bilim Dalı,

İzmir, Türkiye

G. Şakul 0000-0003-1420-3178

E. Divarcı 0000-0002-7617-5427 Ege Üniversitesi Tıp Fakültesi, Çocuk Cerrahi Anabilim Dalı, izmir, Türkiye

H.H. Alper 0000-0002-7096-5292 Ege Üniversitesi Tıp Fakültesi, Radyoloji Anabilim Dalı, Izmir, Türkiye

Cite as: Eşki A, Kartal Öztürk G, Şakul G, Divarcı E, Alper HH, Demir E, et al. Atelectasis: An uncommon sign of achalasia in childhood. Tepecik Eğit. ve Arașt. Hast. Dergisi. 2021;31(1):126-9.

\section{Atelektazi: Çocukluk Çağında Nadir Bir Akalazya Bulgusu}

\author{
Aykut Eşki ๑, Gökçen Kartal Öztürk ๑, Gözde Şakul ๑, Emre Divarcı ๑, \\ Hüseyin Hüdaver Alper $\odot$, Esen Demir $\odot$, Figen Gülen $\odot$
}

\begin{abstract}
An 11-year-old boy presented to our pediatric pulmonology clinic with a 3-month history of atelectasis evident on his chest radiography. Breath sounds revealed fine crackles in the right lower zone and rhonchi in the upper zones. His initial pulmonary function test was compatible with restrictive pulmonary disease. Chest tomography revealed that the trachea, right intermediate, and middle lobe bronchi were narrowed by megaesophagus. Esophagogram determined dilatation of the esophagus and "bird-beak" sign in the esophagogastric junction but it was not sufficient to diagnose. Esophageal manometry which is the gold standard test for achalasia was performed and type 2 achalasia was diagnosed. His symptoms improved following Heller myotomy conducted together with Dor fundoplication. Although respiratory problems are more common in infants and younger children, atypical respiratory presentations may also occur during adolescence. Achalasia should be one of the rare differential diagnoses of pediatric restrictive pulmonary disease.
\end{abstract}

Keywords: Esophageal achalasia, Heller myotomy, pulmonary atelectasis, respiratory function test

Öz

Akciğer grafisinde 3 aydır atelektazi öyküsü olan, 11 yaşında erkek çocuk, Çocuk Göğüs Hastalıklarına başvurdu. Solunum seslerinde, sağ alt zonda ince ral ve üst zonlarda ronküs mevcuttu. Başvurundaki solunum fonksiyon testi restriktif akciğer hastalığı ile uyumlu bulundu. Akciğer tomografisinde; megaözofagus trakea, sağ intermedia ve orta lob bronşlarına dışardan bası yapmaktaydı. ileri tanısal araştırmalarda; özofagogramda özofagus tüm boyunca dilate ve özofagogastrik birleşkede ise "kuşgagası" görünümü görüldü, ancak akalazya tanısı için yeterli değildi. Akalazya tansısı için altın standart test olan özofagus manometresi yapıldı ve tip 2 akalazya teshhisi kondu. Heller miyotomi ve Dor fundoplikasyonu sorasında hastanın semptomları geriledi. Respiratuvar semptomlar infantlarda daha yaygın görülebilirken, adölesan yaş grubunda atipik respiratuvar şikayetler ile karşımıza çıkabilmektedir. Akalazya, çocuklarda restriktif akciğer hastalığııın nadir ayrıcı tanılarından biri olmalıdır.

Anahtar kelimeler: Özofageal akalazya, Heller miyotomi, atelektazi, solunum fonksiyon testi

\section{INTRODUCTION}

Esophageal achalasia (EA) is an uncommon disorder characterized by aperistalsis of the esophagus and defective relaxation of the lower esophageal sphincter (LES). Its estimated incidence in pediatric age is 0.18 per 100.000 and less than $5 \%$ of the cases develop symptoms under 15 years of age ${ }^{(1)}$. Although dysphagia, regurgitation, heartburn and chest pain are the most frequent symp- toms in adults, respiratory manifestations are more frequent in younger children. Because of the rareness of this congenital disease manifesting with different symptoms according to age groups, the diagnosis of patients is delayed for a notable duration. Here, we present an 11-year-old boy who had right inferior and middle lobe atelectasis in the chest radiography (CXR) persisting for 3 months and diagnosed with achalasia.
(C) Telif hakkı TC. Să̆lık Bakanlığı İmir Tepecik Eğit. ve Arastt. Hastanesi. Logos Tıp Yayınclık tarafindan yayınlanmaktadır.

Bu dergide yayınlanan bütün makaleler Creative Commons Atf-GayriTicari 4.0 Uluslararası Lisansı ile lisanslanmıştır.

(c) Copyright Association of Publication of the T.C. Ministry of Health Izmir Tepecik Education and Research Hospital.

This journal published by Logos Medical Publishing.

Licenced by Creative Commons Attribution-NonCommercial 4.0 International (CC BY-NC 4.0) 


\section{CASE REPORT}

An 11-year-old male presented to the pediatric pulmonology clinic, with a persistent atelectasis in his CXR for 3 months.In his previous history, he had radiologically confirmed pneumonia 2 years ago and was treated with antibiotics. He gave a good response to therapy and CXR findings regressed after 15 days of treatment. Atelectasis was determined in his routine examination performed three months ago. Although he received mucolytic and expectorant medications, his atelectasis did not improve.

His personal and family history did not reveal any evidence of consanguinity, atopy, tuberculosis in his first-degree relatives, and sibling death. His weight was below $3^{\text {rd }}$ percentile and height was the $10^{\text {th }}-25^{\text {th }}$ percentile. Breath sounds revealed fine crackles in the right lower zone and rhonchi in bilateral upper zones. He had a BCG scar and other systemic examinations were natural. While the laboratory results did not show any abnormalities, CXR confirmed the presence of atelectasis in the right inferior lobe which was blamed for air-fluid level and dilated esophagus seen on CXR (Figure 1). Any microorganisms did not grow in his bacteriological, mycological, and mycobacterial sputum cultures. The Quantiferon TB Gold test and sweat test yielded negative results. His initial pulmonary function test (PFT) demonstrated a forced vital capacity (FVC) of 0.9 L $(33 \%$

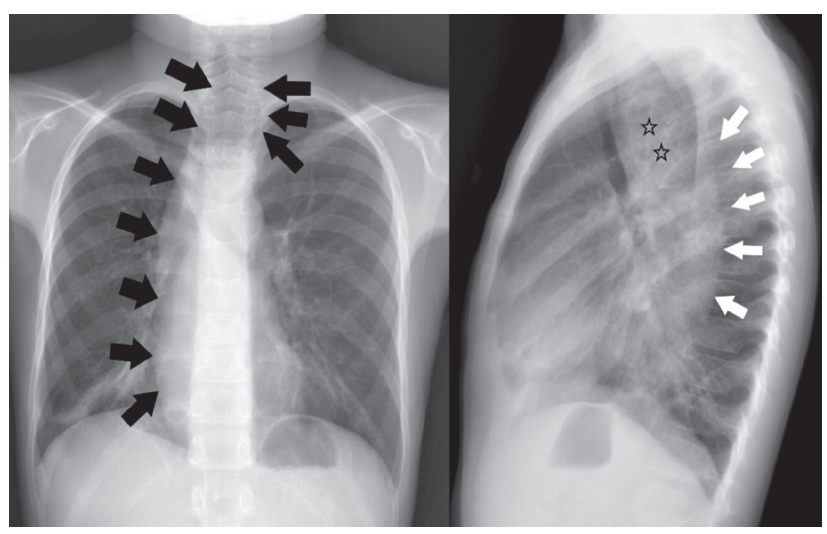

Figure 1. Air-fluid level and food residue in the dilated esophagus and atelectasis. predicted), forced expiratory volume in $1^{\text {st }}$ sec (FEV1) of $0.9 \mathrm{~L}$ (40\% predicted), FEV1/FVC of $116 \%$ and peak expiratory flow (PEF) of $2.97 \mathrm{~L} / \mathrm{sec}$ (60\% predicted). Any change in these parameters did not occur after use of bronchodilators, indicating severe restrictive pulmonary disease. Computed tomography (CT) showed a dilated esophagus that contained food fragments, and measuring $5.2 \times 6.1 \mathrm{~cm}$ at its widest area. Megaesophagus which leads to atelectasis narrowed the trachea, right intermediate, and inferior bronchi (Figure 2,3). Esophagogram showed complete esophageal dilatation which contained food debris, pointed "bird-beak" appearance in the esophagogastric junction, and an insufficient passage to the stomach (Figure 4). We performed esophagus manometry test to arrive at definitive diagnosis

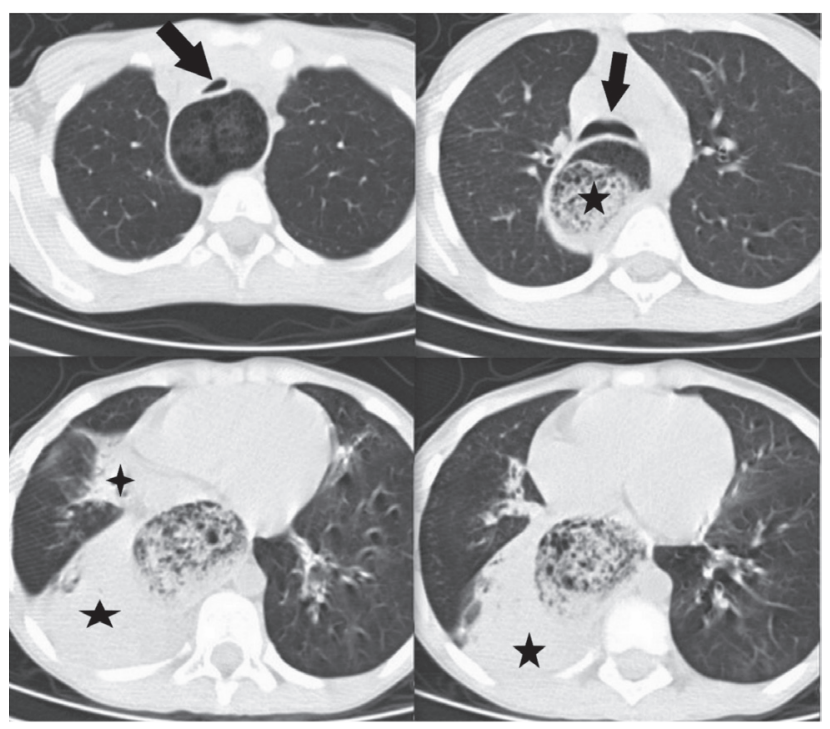

Figure 2. Dilated esophagus narrowing the trachea and atelectasis in the right middle and inferior lobe.

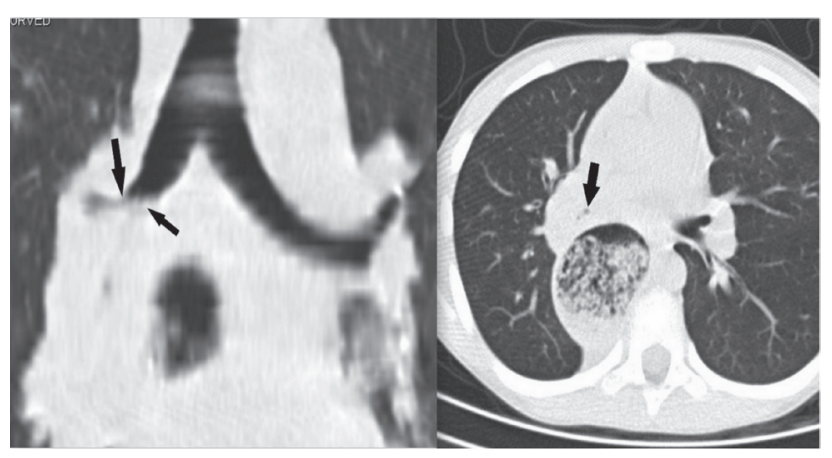

Figure 3. Narrowing of the right intermediate and lower lobe bronchi due to compression by megaesophagus. 
which was consistent with achalasia type 2 [panesophageal pressure and integrated relaxation pressure $\left(\right.$ IRP) $>15 \mathrm{~mm} \mathrm{Hg}{ }^{(2)}$. During esophagoscopy,the contents in the esophagus were aspirated and solid fragments were removed with foreign body clamp. Then Heller myotomy combined with Dor fundoplication was implemented. Postoperative CXR showed improvement in atelectasis and air in the dilated esophagus (Figure 5). The results of PFT performed 3 months after surgery were as follows: FVC; $2,4 \mathrm{~L}$ (85\% predicted), FEV1; 2.12 L (91\% predicted), FEV1/ FVC; $103 \%$, and PEF; $4.67 \mathrm{~L} / \mathrm{sec}$ (91\% predicted). No further complaints and complications were observed during the follow-up period of 24 months and he

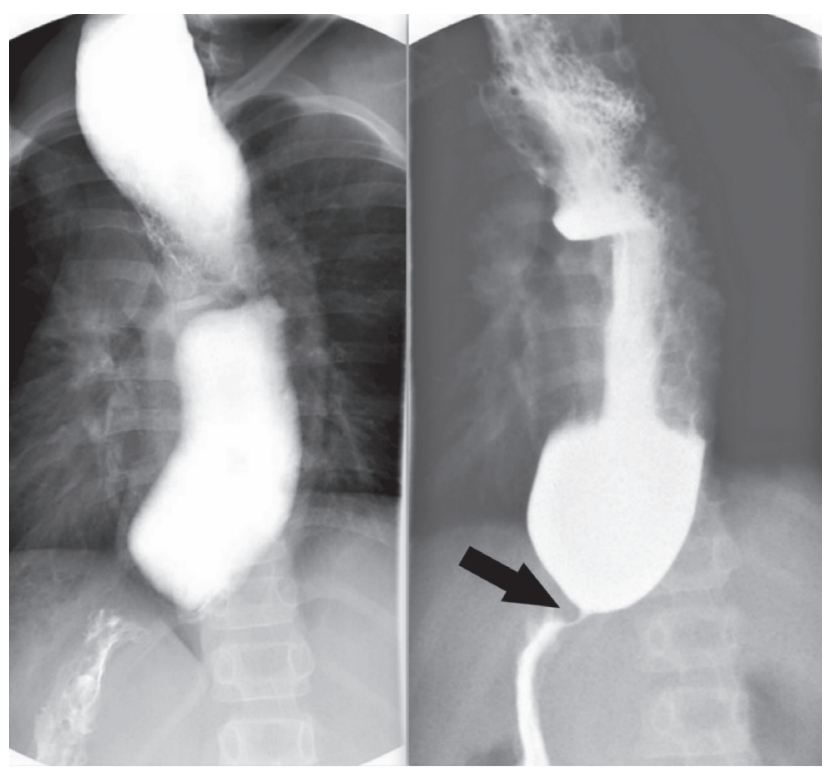

Figure 4. Esophagogram (lying): Esophageal dilatation was seen. Esophagogram (standing): Narrowing of the passage to stomach, "bird-beak" sign.

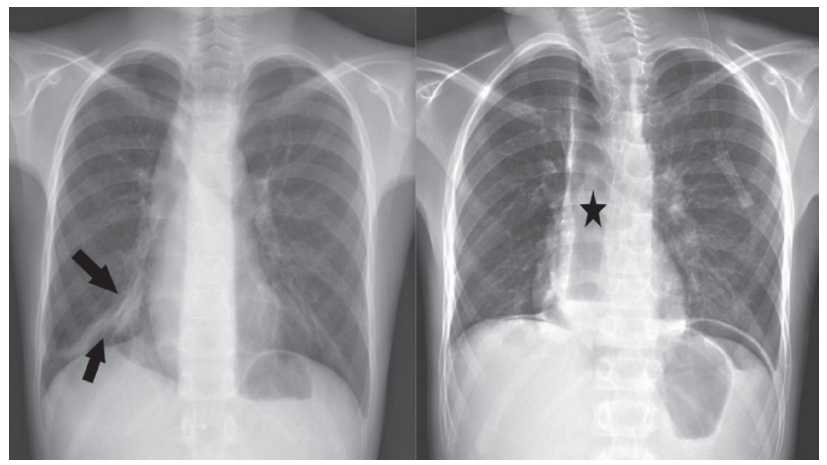

Figure 5. Regression of the right lower lobe atelectasis, and air-filled dilated esophagogram. gained $3 \mathrm{~kg}$ in a month. Informed consent was obtained from our patient and his parents.

\section{DISCUSSION}

Pediatric achalasia is a lifelong, debilitating condition, with a significant impact on the quality of life. It is usually misdiagnosed and may lead to poorer growth since pediatricians are not conscious of this diagnosis and its manifestations. It is more often diagnosed between 7-15 years of age with a slight predominance in boys ${ }^{(3)}$. The symptoms are age-related. Children and adults present with regurgitation (76-91\%), weight loss (35-91\%) and aspiration pneumonia $(30 \%)^{(4)}$. Most children are treated as GER, and this misdiagnosis leads to development of persisting symptoms, and failure to thrive ${ }^{(5)}$. When compared to children, adults are more likely to experience respiratory symptoms as biphasic stridor and/ or atelectasis because of the compression of the airway by megaesophagus ${ }^{(6)}$. Barr and et al. ${ }^{(7)}$ reported a case with tracheomalacia secondary to compression by megaesophagus that presented with complaints of stridor. In another study conducted by Makharia et al. ${ }^{(8)}$ compression of the tracheobronchial tree was observed in 8 patients with esophageal dilatation, but none of the patients had atelectasis. In our case, CT revealed that the dilated esophagus compressed the trachea from the outside. However, both the right intermediate and inferior lobe bronchi were narrowed and, caused atelectasis in our patient. Atelectasis is not a diagnosis, so etiology-related further research should be worked out for these patients. Parshad et al. ${ }^{(9)}$ reported restrictive pulmonary function in six patients, and only one patient's PFT improved. We demonstrated that the restrictive lung disease of our patient was completely resolved at 3 months after surgery. Although respiratory arrest associated with achalasia has not been reported in children, some reports in adults showed that it might be a life-threating disease when misdiagnosed or diagnosis is delayed. Thus, we suggest that achalasia should be investigated in children with 
respiratory symptoms. The diagnosis of achalasia is suggested by typical clinical symptoms, and confirmed with specific evaluation methods which include barium esophagogram, esophagus manometry and upper digestive endoscopy ${ }^{(9)}$. A barium esophagogram is useful in immediate diagnosis and exclusion of the structural anomalies of the esophagus by estimating esophageal diameter and revealing epiphrenic diverticulum. It may demonstrate a smooth proximal esophagus with the narrowed distal esophagus, named a bird-beak sign. Moreover, existence of food and fluid in the esophagus may cause a dilated or tortuous esophagus ${ }^{(5)}$. While both clinical and radiological findings confirm achalasia, esophagus manometry is considered as the gold standard test for diagnosing and subtyping ${ }^{(6)}$. The findings supporting the diagnosis of achalasia include elevated LES pressure, the absence of LES relaxation during swallowing, or the presence of low amplitude waves featured with non-progression or absence of primary peristaltic waves ${ }^{(5)}$. Although there is no established protocol to treat EA in the pediatric population, palliative management targeting at reducing patients' symptoms, improving esophageal emptying, and preventing formation of a megaesophagus is preferred. On the other hand, considering surgical treatments, Heller myotomy, which has more reliable outcomes than pneumatic dilation in the long-term follow-up, might be a better choice for children's treatment. Moreover, the shorter hospital duration, fewer analgesic use, and quicker return to daily activities with better cosmetic results have further encouraged the physicians to perform Heller myotomy ${ }^{(10)}$.
In conclusion, to the best of our knowledge, this is the first pediatric case in the Turkish literature of achalasia presenting with atelectasis. Several pediatric cases reported that patients present with chronic cough and stridor, caused by aspiration and fixed upper airway obstruction. This case emphasizes inclusion of gastrointestinal conditions in the differential diagnosis of achalasia in children presenting with persistent atelectasis.

Conflict of Interest: None. Informed Consent: None.

\section{REFERENCES}

1. Nurko S. Motility Disorders in Children. Pediatr Clin North Am. 2017;64(3):593-612. [CrossRef]

2. Kahrilas PJ, Bredenoord AJ, Fox M, et al. The Chicago Classification of esophageal motility disorders. NeurogastroenterolMotil. 2015;27(2):160-74. [CrossRef]

3. Smits M, van Lennep M, Vrijlandt R, et al. Pediatric Achalasia in the Netherlands: Incidence, Clinical Course, and Quality of Life. J Pediatr. 2016;169:110-5. [CrossRef]

4. Fernandez PM, Lucio LA, Pollachi F. Esophageal achalasia of unknown etiology in children. J Pediatr (Rio J). 2004;80(6):523-6. [CrossRef]

5. Karnak I, Senocak EM, Tanyel FC, et al. Achalasia in childhood: surgical treatment and outcome. Eur J pediatr Surg. 2001;11(4):223-9. [CrossRef]

6. van Lennep, M., van Wijk, M. P., Omari, T. I., et al. Clinical management of pediatric achalasia. Expert review of gastroenterology \& hepatology. 2018;12(4):391-404. [CrossRef]

7. Barr JG, Dean H, Morrison G. A rare case of paediatric stridor caused by achalasia. J Laryngol Otol. 2015;129(7):725-6. [CrossRef]

8. Makharia GK, Seith A, Sharma SK, et al. Structural and functional abnormalities in lungs in patients with achalasia. Neurogastroenterol Motil. 2009;21(6):603-8. [CrossRef]

9. Parshad R, Devana SK, Panchanatheeswaran K, et al. Clinical, radiological and functional assessment of pulmonary status in patients with achalasia cardia before and after treatment. Eur J Cardiothorac Surg. 2012;42(5):e90-5. [CrossRef]

10. Caldaro T, Familiari P, Romeo FE, et al. Treatment of esophageal achalasia in children: Today and tomorrow. J Pediatr Surg. 2015;50(5):726-30. [CrossRef] 